\title{
Visual Census of the Reef Fishes in the Natural Reserve of the Glorieuses Islands (Western Indian Ocean)
}

\author{
P. Durville ${ }^{1,2}$, P. Chabanet ${ }^{2}$ and J.P. Quod ${ }^{3}$ \\ ${ }^{1}$ Aquarium de La Réunion, Centre de découverte du milieu marin réunionnais, Port de plaisance de Saint-

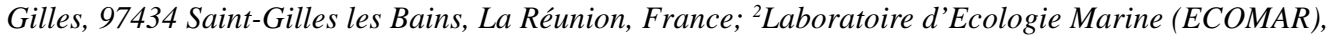 \\ Université de La Réunion, Avenue René Cassin, 97715 Saint-Denis Messag. Cedex 9, La Réunion, France; \\ ${ }^{3}$ Agence pour la Recherche et la Valorisation Marine (ARVAM), 14 rue du stade de l'Est, 97490 Sainte- \\ Clotilde, La Réunion, France
}

\begin{abstract}
Key words: visual census, reef fishes, natural reserve, Glorieuses Islands, western Indian Ocean
Abstract-This paper constitutes the first qualitative study of coral reef fish populations in the archipelago of the Glorieuses Islands (northern Mozambique Channel). Sampling by visual census techniques, at depths between 0 and 15 meters, was carried out at 30 stations spread over the whole reef. Three hundred and thirty-two (332) fish species belonging to 57 families were registered in this way. These relatively high numbers show that isolated coral reef formations, even of small size, can be endowed with a great specific richness of reef ichthyofauna. These results may be explained by an oceanic flow that favours recruitment, a diversified habitat, and low anthropogenic impact.
\end{abstract}

\section{INTRODUCTION}

Located in the western Indian Ocean, the Glorieuses Archipelago (11 $\left.{ }^{\circ} 29^{\prime} \mathrm{S}, 4^{\circ} 23^{\prime} \mathrm{E}\right)$ is part of the five islands 'Iles Eparses', including Juan de Nova, Bassas da India, Europa and Tromelin. These French overseas territories, dispersed around Madagascar, have an Exclusive Economic Zone and cover nearly $650,000 \mathrm{~km}^{2}$ (Gabrié, 1998). Four of the islands were classified as natural reserves in 1975, the exception being Juan de Nova (Le Corre \& Safford, 2001). Oceanographical research in these environments was restarted a few years ago under the direction of the IFRECOR (Initiative Française pour les Récifs Coralliens) after periods of coral bleaching in the region in 1998. One of the main areas of research consists in the evaluation of the specific richness of the coral reef and the drawing up of an index as a means to conceive a management plan and preservation of the environment. Over the last 25 years, only a few selective missions have enabled observations of some invertebrates and the morphology of the islands (Vergonzanne, 1977; Battistini \& Cremers, unpublished data). More recently, research has been conducted on beach dynamics (Troadec, unpublished data) and sea birds (Le Corre \& Safford, 2001). To our knowledge, no data have been published on the ichthyological fauna of this reef area. Therefore, the present study was carried out with the objective of establishing a baseline inventory of reef fish species of the Glorieuses Islands, followed by a discussion of the particularities of this archipelago.

\section{MATERIALS AND METHODS}

The Glorieuses archipelago is composed of two principal coral islands, the 'Grande Glorieuse', which is $3 \mathrm{~km}$ in diameter and characterised by a group of dunes attaining an altitude of $12 \mathrm{~m}$, and the 'Petite Glorieuse' (or Lys Island), with a

Corresponding author: PD.

E-mail: aquarium.reunion@wanadoo.fr 


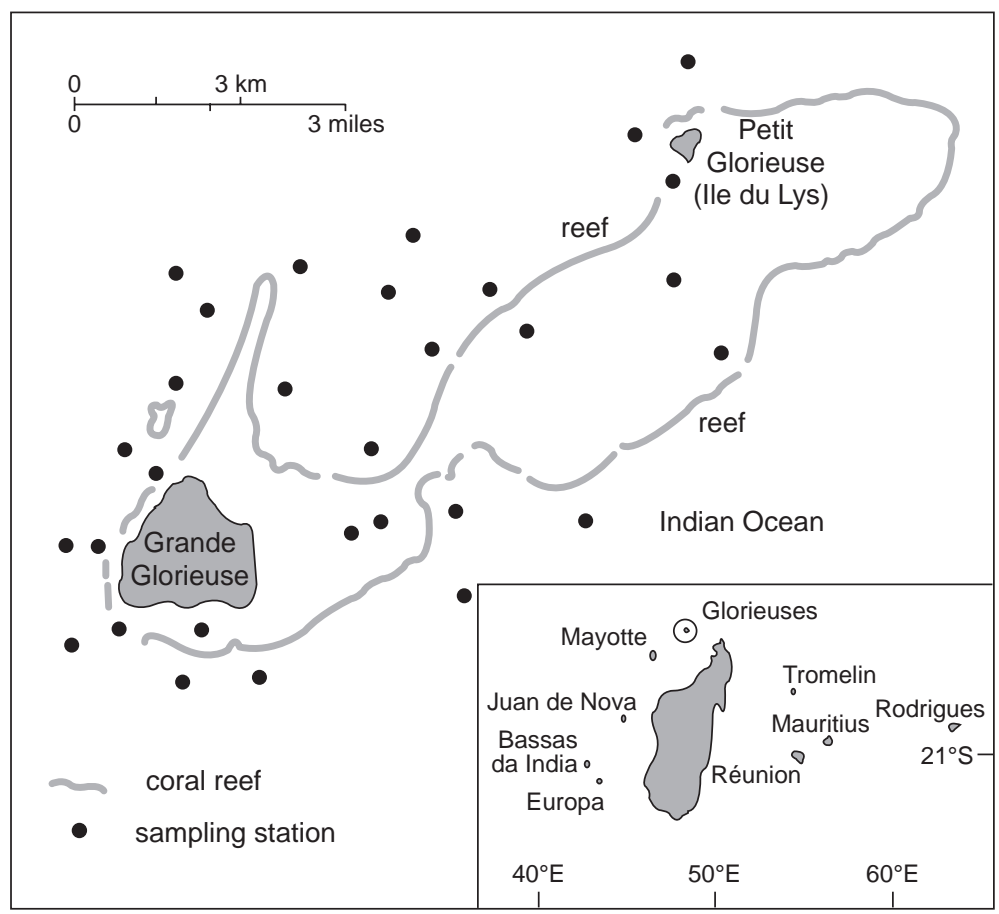

Fig. 1. Geographical location of the Glorieuses Islands and the position of sampling stations

diameter of $0.6 \mathrm{~km}$ and a bog formation at its centre. Two rock formations, the 'Roches Vertes' and 'Crabes Island', along with sandbars that more or less emerge at low tide, complete the archipelago. The whole of the coral formation represents an area of about $7 \mathrm{~km}^{2}$. It is a coral bank built on a shoal (Vergonzanne, 1977), so there are no distinct geomorphologic areas, apart from a few fringe formations found around the two principal islands (Fig.1).

The oceanographic fieldwork took place over a 10-day period in the beginning of November, 2002 (Austral summer). Sampling of species richness was conducted by underwater visual census techniques, mainly using a slate associated with video recording devices, at a depth of 0 and 15 metres. Using this visual method, qualitative results can be obtained without disturbing the population, though the small and cryptic components of the fish fauna are underestimated (Fowler, 1987). A total of 30 stations distributed along the reef (Fig. 1) were positioned by 1 or 2 divers who moved randomly over the area for 30 minutes, carefully indexing each new species. Finally, a study on the diet feeding habits (according to Hiatt \& Strasburg, 1960; Hobson, 1974; Harmelin-Vivien, 1979; Myers, 1999) was carried out and height trophic categories were considered: herbivores, omnivores, browsers of sessile invertebrates, diurnal carnivores, nocturnal carnivores, piscivores, diurnal planktivores and nocturnal planktivores.

\section{RESULTS}

\section{Species richness}

In total, 332 species belonging to 57 families were observed (Table 1). Only 5 species were cartilaginous fishes (Chondrichthyes), the 327 others being bony fishes (Osteichthyes). It was noted that $48 \%$ of the species belong to 6 principal families: the Labridae with the highest representation (45 species), the Pomacentridae (34 species), the Serranidae (27 species), the Acanthuridae (24 species), the Chaetodontidae (17 species), and finally the Scaridae (14 species). The remaining 52\% included 51 families, where 23 (e.g. Carcharhinidae, Haemulidae) were represented only by a single species each. 
Table 1. Inventory of the reef fishes of the Glorieuses Islands (from depths of 0-15 m)

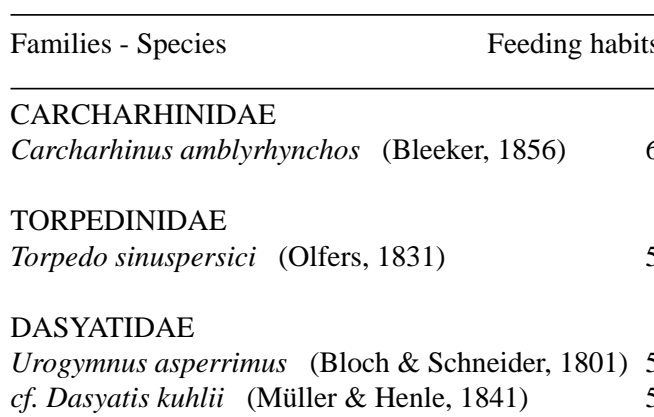

\section{MYLIOBATIDAE}

Aetobatus narinari (Euphrasen, 1790)

\section{MURAENIDAE}

Echidna nebulosa (Ahl, 1789)

Gymnothorax flavimarginatus (Rüppell, 1830)

Gymnothorax javanicus (Bleeker, 1859)

Gymnothorax meleagris (Shaw \& Nodder, 1795)

Rhinomuraena quaesita Garman, 1888

Siderea picta (Ahl, 1789)

\section{OPHICHTHIDAE}

Ophichthidae sp.

\section{CONGRIDAE}

Congridae sp.

Heteroconger hassi (Klausewitz \&

Eibl-Eibesfeldt, 1959)

\section{SYNODONTIDAE}

Saurida gracilis (Quoy \& Gaimard, 1824)

Synodus variegatus (Lacepède, 1803)

Synodus sp.

CLUPEIDAE

Clupeidae sp.

Spratelloides sp.

ENGRAULIDAE

Engraulidae sp.

BELONIDAE

Belonidae sp.

HEMIRAMPHIDAE

Hemiramphus sp.

ANTENNARIIDAE

Antennarius sp.

\section{HOLOCENTRIDAE}

Myripristis adusta Bleeker, 1853

Myripristis berndti (Jordan \& Evermann, 1903)

Myripristis murdjan (Forsskål, 1775)
Table 1. continued

Families - Species

Feeding habits

Neoniphon opercularis (Valenciennes in Cuvier \& Valenciennes, 1831)

Neoniphon sammara (Forsskål, 1775)

Sargocentron caudimaculatum (Rüppell, 1838) 5

Sargocentron diadema (Lacepède, 1802) 5

Sargocentron inaequalis Randall \&

Heemstra, 1985

5

Sargocentron spiniferum (Forsskål, 1775)

AULOSTOMIDAE

Aulostomus chinensis (Linné, 1766)

4 FISTULARIIDAE

Fistularia commersonii Rüppell, 1838

SCORPAENIDAE

Pterois miles (Bennett, 1828) 6

Scorpenopsis sp.

Scorpenopsis cf. oxycephala

CARACANTHIDAE

Caracanthus madagascariensis (Guichenot, 1869) 5

5 SERRANIDAE

Aethaloperca rogaa (Forsskål, 1775) 5

Cephalopolis argus Bloch \& Schneider, 1801

Cephalopolis miniata (Forsskål, 1775) 5

Cephalopolis nigripinnis (Valenciennes, 1828) 5

Cephalopolis sexmaculata (Rüppell, 1830) 5

Cephalopolis urodeta (Bloch \& Schneider, 1801) 5

Epinephelus fasciatus (Forsskål, 1775) 5

Epinephelus flavocaeruleus (Lacepède, 1801) 6

Epinephelus fuscoguttatus (Forsskål, 1775) 6

Epinephelus hexagonatus (Forster in

Bloch \& Schneider, 1801)

Epinephelus longispinis (Kner, 1864)

Epinephelus malabaricus (Bloch \& Schneider, 1801)

Epinephelus merra Bloch, 1793

7 Epinephelus polyphekadion (Bleeker, 1849) 6

Epinephelus spilotoceps Schultz, $1953 \quad 5$

Epinephelus tauvina (Forsskål, 1775) 6

Epinephelus tukula Morgans, 1959

Nemanthias carberryi Smith, $1954 \quad 7$

Plectropomus laevis (Lacepède, 1801) 6

2 Plectropomus pessuliferus Fowler, $1904 \quad 6$

Plectropomus punctatus (Quoy \& Gaimard, 1824) 6

Pseudanthias cooperi (Regan, 1902) 7

$\begin{array}{lll}\text { Pseudanthias evansi (Smith, 1954) } & 7\end{array}$

Feeding habits- 1 : herbivores; 2 : omnivores; 3 : browsers of sessile invertebrates; 4 : diurnal carnivores; 5 : nocturnal carnivores; 6: piscivores; 7: diurnal planktivores; 8: nocturnal planktivores. 


\section{Table 1. continued}

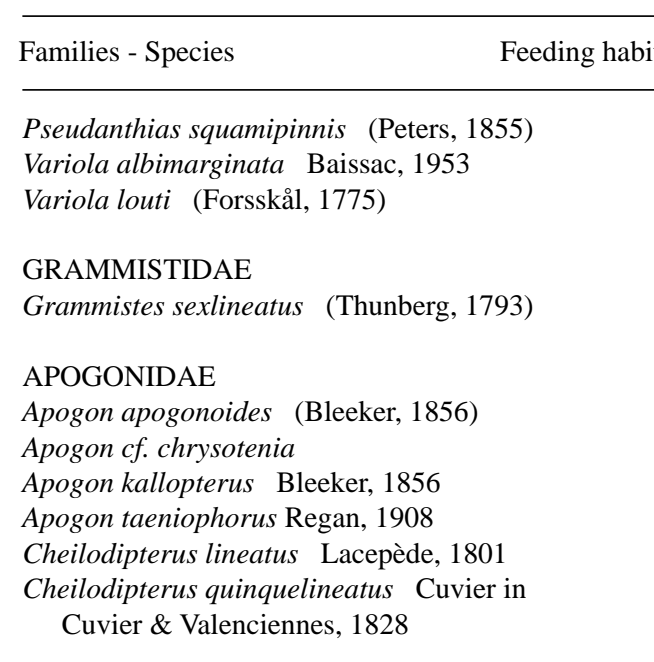

\section{KUHLIIDAE}

Kuhlia mugil (Forster in Bloch \& Schneider, 1801) 7

\section{GERREIDAE}

Gerres oeyena (Forsskål, 1775)

Gerres sp.

\section{HAEMULIDAE}

Plectorhinchus vittatus (Linnaeus, 1758)

\section{LUTJANIDAE}

Aphareus furca (Lacepède, 1801)

Aprion virescens Valenciennes in Cuvier \& Valenciennes, 1830

Lutjanus bohar (Forsskål, 1775)

Lutjanus fulvus (Forster in Bloch \& Schneider, 1801)

Lutjanus gibbus (Forsskål, 1775)

Lutjanus kasmira (Forsskål, 1775)

Lutjanus monostigma (Cuvier in Cuvier \& Valenciennes, 1828)

Lutjanus rivulatus (Cuvier in Cuvier \& Valenciennes, 1828)

Macolor niger (Forsskål, 1775)

\section{CAESIONIDAE}

Caesio caerulaurea Lacepède, 1801

Caesio lunaris Cuvier in Cuvier \& Valenciennes, 1828

Caesio striata Rüppell, 1830

Caesio teres Seale, 1906

Caesio xanthonota Bleeker, 1853

Pterocaesio marri Schultz, 1953

Pterocaesio tile (Cuvier in Cuvier \& Valenciennes, 1828)

\section{LETHRINIDAE}

Gnathodentex aureolineatus (Lacepède, 1802) Gymnocranius grandoculis (Valenciennes in

7

\section{Table 1. continued}

$$
\text { Families - Species }
$$

Feeding habits

Cuvier \& Valenciennes, 1830)

Lethrinus cf. atkinsoni (Seale, 1909)

Lethrinus erythracanthus Valenciennes in Cuvier \& Valenciennes, 1830

Lethrinus mahsena (Forsskål, 1775)

Lethrinus rubrioperculatus Sato, 1978

Lethrinus xanthochilus Klunzinger, 1870

Lethrinus sp.

Monotaxis grandoculis (Forsskål, 1775)

\section{5}

MULLIDAE

Mulloidichthys flavolineatus (Lacepède, 1801) 5

Mulloidichthys vanicolensis (Valenciennes in

Cuvier \& Valenciennes, 1831)

Parupeneus barberinus (Lacepède, 1801)

Parupeneus cyclostomus (Lacepède, 1801)

Parupeneus indicus (Russell \& Shaw, 1803)

Parupeneus macronemus (Lacepède, 1801)

Parupeneus pleurostigma (Bennett, 1832)

Parupeneus porphyreus (Jenkins, 1902)

Parupeneus trifasciatus (Lacepède, 1801)

KYPHOSIDAE

Kyphosus cinerascens (Forsskål, 1775)

\section{EPHIPPIDAE}

Platax sp.

\section{POMACANTHIDAE}

Apolemichthys trimaculatus (Lacepède in

Cuvier \& Valenciennes, 1831)

Centropyge acanthops (Norman, 1922)

Centropyge bispinosus (Günther, 1860)

Centropyge multispinis (Playfair, 1867)

Pomacanthus imperator (Bloch, 1787)

Pomacanthus semicirculatus (Cuvier in

Cuvier \& Valenciennes, 1831)

Pygoplites diacanthus (Boddaert, 1772)

5 CHAETODONTIDAE

Chaetodon auriga Forsskål, 1775

Chaetodon falcula Bloch, 1793

Chaetodon guttatissimus Bennett, 1832

Chaetodon kleinii Bloch, 1790

Chaetodon lineolatus (Quoy \& Gaimard in

Cuvier \& Valenciennes, 1831)

Chaetodon lunula (Lacepède, 1802)

Chaetodon madagaskariensis Ahl, 1923

Chaetodon meyeri Bloch \& Schneider, 1801

Chaetodon trifascalis Quoy \& Gaimard, 1825

Feeding habits- 1: herbivores; 2: omnivores; 3 : browsers of sessile invertebrates; 4 : diurnal carnivores; 5 : nocturnal carnivores; 6: piscivores; 7: diurnal planktivores; 8: nocturnal planktivores. 
Table 1. continued

\begin{tabular}{lr}
\hline Families - Species & Feeding habits \\
\hline Chaetodon trifasciatus trifasciatus Mungo & 3 \\
$\quad$ Park, 1797 & 3 \\
Chaetodon unimaculatus interruptus Ahl, 1923 \\
Chaetodon vagabundus Linnaeus, 1758 \\
Chaetodon xanthocephalus Bennett, 1832 \\
Chaetodon zanzibariensis Playfair in \\
$\quad$ Playfair \& Günther, 1867 \\
Forcipiger longirostris (Broussonet, 1782) \\
Hemitaurichthys zoster (Bennett, 1831) \\
Heniochus monoceros Cuvier in \\
$\quad$ Cuvier \& Valenciennes, 1831
\end{tabular}

MALACANTHIDAE

Malacanthus brevirostris Guichenot, 1848

Malacanthus latovittatus (Lacepède, 1801)

ECHENEIDAE

Echeneis naucrates Linnaeus, 1758

\section{CARANGIDAE}

Carangoides orthogrammus Jordan \& Gilbert, 18826

Caranx ignobilis (Forsskål, 1775)

Caranx melampygus Valenciennes in

Cuvier \& Valenciennes, 1833

Caranx sexfasciatus Quoy \& Gaimard, 1825

Elagatis bipinnulata (Quoy \& Gaimard, 1825)

Scomberoides lysan (Forsskål, 1775)

Trachinotus baillonii (Commerson \& Lacepède in Lacepède, 1801)

Trachinotus blochii (Commerson \&

Lacepède in Lacepède, 1801)

CIRRHITIDAE

Cirrhitichthys oxycephalus (Bleeker, 1855)

Paracirrhites arcatus (Parkinson in Cuvier \&

Valenciennes, 1829)

Paracirrhites forsteri (Bloch \& Schneider, 1801)

\section{PEMPHERIDAE}

Parapriacanthus ransonneti Steindachner, $1870 \quad 8$

Pempheris schwenkii Bleeker, 1855

Pempheris vanicolensis Cuvier in Cuvier \&

Valenciennes, 1831

\section{POMACENTRIDAE}

Abudefduf notatus (Day, 1870)

Abudefduf sexfasciatus (Commerson \&

Lacepède in Lacepède, 1801)

Abudefduf sparoides (Quoy \& Gaimard, 1825)

Abudefduf vaigiensis (Quoy \& Gaimard, 1825)

Amblyglyphidodon leucogaster (Bleeker, 1847)

Amphiprion akallopisos Bleeker, 1853

Amphiprion allardi Klausewitz, 1970

Chromis atripectoralis Welander \& Schultz, 1951

Chromis dimidiata (Klunzinger, 1871)

\section{Table 1. continued}

Families - Species

Feeding habits

Chromis nigrura Smith, 1960

Chromis opercularis (Günther, 1867) 7

Chromis ternatensis (Bleeker, 1856) 7

Chromis weberi Fowler \& Bean, 1928

Chrysiptera biocellata (Quoy \& Gaimard, 1825) 2

Chrysiptera glauca (Cuvier in Cuvier \&

Valenciennes, 1830) 2

Chrysiptera leucopoma (Lesson in Cuvier \&

Valenciennes, 1830)

Chrysiptera unimaculata (Cuvier, 1830)

Dascyllus aruanus (Linnaeus, 1758)

Dascyllus carneus Fischer, 1885

Dascyllus trimaculatus (Rüppell, 1829)

Lepidozygus tapeinosoma (Bleeker, 1856)

Neoglyphidodon melas (Cuvier, 1830)

Plectroglyphidodon dickii (Liénard, 1839)

Plectroglyphidodon johnstonianus Fowler \& Ball, 1924

Pomacentrus caeruleus Quoy \& Gaimard, 1825

Pomacentrus pavo (Bloch, 1787)

Pomacentrus sulfureus Klunzinger, 1871

Pomacentrus trichrourus Günther, 1877

Pomacentrus sp.1

Pomacentrus sp. 2 cf. coelestis

Stegastes albifasciatus (Schlegel \& Müller, 1839) 1

Stegastes fasciolatus (Ogilby, 1889)

Stegastes nigricans (Lacepède, 1802)

Stegastes pelicieri Allen \& Emery, 1985

\section{LABRIDAE}

Anampses caeruleopunctatus Rüppell, $1829 \quad 4$

Anampses lineatus Randall, 1972

Anampses meleagrides Valenciennes in Cuvier \&

Valenciennes, 1840

Anampses twistii Bleeker, 1856

Bodianus anthioides (Bennett, 1832)

Bodianus axillaris (Bennett, 1832)

Bodianus bilunulatus bilunulatus (

Bodianus diana (Lacepède, 1801) 4

Cheilinus fasciatus fasciatus (Bloch, 1791) 4

Cheilinus oxycephalus Bleeker, $1853 \quad 4$

Cheilinus trilobatus Commerson \& Lacepède in Lacepède, 1801

Cheilinus undulatus Rüppell, 1835

Cirrhilabrus exquisitus Smith, 1957

Coris africana Smith, 1957

Coris aygula Lacepède, 1801

Coris caudimacula (Quoy \& Gaimard, 1834)

Cymolutes sp.

Epibulus insidiator (Pallas, 1770)

Feeding habits- 1 : herbivores; 2 : omnivores; 3 : browsers of sessile invertebrates; 4 : diurnal carnivores; 5 : nocturnal carnivores; 6: piscivores; 7: diurnal planktivores; 8 : nocturnal planktivores. 


\section{Table 1. continued}

Families - Species

Feeding habits

Gomphosus caeruleus caeruleus Lacepède, 1801

Halichoeres cosmetus Randall \& Smith, 1982

Halichoeres hortulanus (Lacepède, 1801)

Halichoeres iridis Randall \& Smith, 1982

Halichoeres marginatus Rüppell, 1835

Halichoeres nebulosus (Valenciennes in Cuvier \& Valenciennes, 1839)

Halichoeres scapularis (Bennett, 1832)

Hemigymnus fasciatus (Bloch, 1792)

Hemigymnus melapterus (Bloch, 1791)

Hologymnosus doliatus (Lacepède, 1801)

Labroides bicolor Fowler \& Bean, 1928

Labroides dimidiatus (Valenciennes in Cuvier \& Valenciennes, 1839)

Labropsis xanthonota Randall, 1981

Macropharyngodon bipartitus bipartitus Smith, 19574

Novaculichthys taeniourus (Lacepède, 1801)

Oxycheilinus digrammus (Lacepède, 1801)

Pseudocheilinus evanidus Jenkins, 1901

Pseudocheilinus hexataenia (Bleeker, 1857)

Pseudocheilinus octotaenia Jenkins, 1901

Pteragogus flagellifer (Valenciennes in Cuvier \&

Valenciennes, 1839)

Stethojulis albovittata (Bonnaterre, 1788)

Thalassoma amblycephalum (Bleeker, 1856)

Thalassoma hardwicke (Bennett, 1830)

Thalassoma hebraicum (Lacepède, 1801)

Thalassoma lunare (Linnaeus, 1758)

Thalassoma sp.

Xyrichtys pavo Valenciennes in Cuvier \& Valenciennes, 1840

SCARIDAE

Bolbometopon muricatum (Valenciennes in Cuvier \& Valenciennes, 1840)

Cetoscarus bicolor (Rüppell, 1829)

Chlorurus sordidus (Forsskål, 1775)

Chlorurus strongylocephalus (Bleeker, 1847)

Hipposcarus harid (Forsskål, 1775)

Scarus caudofasciatus (Günther, 1862)

Scarus frenatus Lacepède, 1802

Scarus niger Forsskål, 1775

Scarus rubroviolaceus Bleeker, 1847

Scarus russellii Valenciennes in Cuvier \& Valenciennes, 1840

Scarus scaber Valenciennes in Cuvier \& Valenciennes, 1840

Scarus sp. 1

Scarus sp.2

Scarus sp. 3

SPHYRAENIDAE

Sphyraena barracuda (Walbaum,1792)
Table 1. continued

Families - Species

Feeding habits

MUGILIDAE

Mugilidae sp.

2

PINGUIPEDIDAE

Parapercis hexophtalma (Ehrenberg in Cuvier \& Valenciennes, 1829)

Parapercis punctulata (Cuvier in Cuvier \&

Valenciennes, 1829)

Parapercis sp.

CALLIONYMIDAE

Synchiropus stellatus Smith, 1963

Diplogrammus infulatus Smith, 1963

BLENNIDAE

Aspidontus dussumieri (Valenciennes in Cuvier \& Valenciennes, 1836)

Cirripectes sp.

Ecsenius midas Starck, 1969

Ecsenius sp.

Exallias brevis (Kner, 1868)

Istiblennius sp.

Meiacanthus mossambicus Smith, 1954

Plagiotremus rhinorhynchos (Bleeker, 1852) 4

Plagiotremus tapeinosoma (Bleeker, 1857)

Blenniidae sp.

\section{MICRODESMIDAE}

Gunnellichthys sp.

Nemateleotris magnifica Fowler, 1938

Ptereleotris evides (Jordan \& Hubbs, 1925)

Ptereleotris heteroperca (Bleeker, 1855)

Ptereleotris zebra Fowler, 1938

\section{GOBIIDAE}

Amblyeleotris sungami (Klausewitz, 1969) 2

Eviota sp. $\quad 2$

Fusigobius sp. $\quad 2$

Gnatholepsis sp. $\quad 2$

Lotilia graciliosa Klausewitz, 1960

Valenciennea helsdingenii (Bleeker, 1858) 4

Valenciennea strigata (Broussonet, 1782) 4

Gobiidae sp.1

Gobiidae sp. 2

\section{ACANTHURIDAE}

Acanthurus bariene Lesson, 1830

Acanthurus dussumieri Valenciennes in Cuvier \&

Valenciennes, 1835

Acanthurus leucosternon Bennett, 1833

Feeding habits- 1 : herbivores; 2 : omnivores; 3 : browsers of sessile invertebrates; 4 : diurnal carnivores; 5 : nocturnal carnivores; 6: piscivores; 7: diurnal planktivores; 8: nocturnal planktivores. 
Table 1. continued

\begin{tabular}{l} 
Families - Species \\
\hline Acanthurus lineatus (Linnaeus, 1758) \\
Acanthurus mata Russell in Cuvier, 1829 \\
Acanthurus nigricauda Duncker \& Mohr, 1929 \\
Acanthurus nigrofuscus (Forsskål, 1775) \\
Acanthurus tennentii Günther, 1861 \\
Acanthurus thompsoni (Fowler, 1923) \\
Acanthurus triostegus triostegus (Linnaeus, 1758) \\
Acanthurus xanthopterus (Valenciennes in \\
Cuvier \& Valenciennes, 1835) \\
Ctenochaetus binotatus Randall, 1955 \\
Ctenochaetus striatus (Quoy \& Gaimard, 1825) \\
Ctenochaetus strigosus (Bennett, 1828) \\
Naso brachycentron (Valenciennes in \\
Cuvier \& Valenciennes, 1835) \\
Naso brevirostris (Cuvier, 1829)
\end{tabular}

Naso hexacanthus (Bleeker, 1855)

Naso lituratus (Forster in Bloch \& Schneider, 1801) 1

Naso thynnoides (Valenciennes in

Cuvier \& Valenciennes, 1835)

Naso tuberosus Lacepède, 1801

Naso unicornis (Forsskål, 1775)

Paracanthurus hepatus (Linné, 1766)

Zebrasoma scopas (Cuvier, 1829)

Zebrasoma velifer (Bloch, 1795)

\section{ZANCLIDAE}

Zanclus canescens (Linnaeus, 1758)

SIGANIDAE

Siganus laqueus (Bonde, 1934)

Siganus sutor (Valenciennes in Cuvier \&

Valenciennes, 1835)

Siganus sp.

BOTHIDAE

Bothus mancus (Broussonet, 1782)

SCOMBRIDAE

Gymnosarda unicolor (Rüppell, 1836)

\section{BALISTIDAE}

Balistapus undulatus (Mungo Park, 1797)

Balistoides conspicillum (Bloch \&

Schneider, 1801)

Balistoides viridescens (Bloch \&

Schneider, 1801)

Melichthys niger (Bloch, 1786)

Pseudobalistes flavimarginatus (Rüppell, 1829)

Rhinecanthus aculeatus (Linnaeus, 1758)

Rhinecanthus rectangulus (Bloch \&

Schneider, 1801)

Sufflamen bursa (Bloch \& Schneider, 1801)

Sufflamen chrysopterus (Bloch \&

Schneider, 1801)

Sufflamen fraenatus (Latreille, 1804)
Table 1. continued

Families - Species

Feeding habits

MONACANTHIDAE

Amanses scopas (Cuvier, 1829)

Cantherhines dumerilii (Hollard, 1854)

Cantherhines pardalis (Rüppell, 1837)

3

3

OSTRACIIDAE

Lactoria cornuta (Linnaeus, 1758) 3

Ostracion cubicus Linnaeus, 1758

Ostracion meleagris Shaw in Shaw \& Nodder, 17963

TETRAODONTIDAE

Arothron hispidus (Linné, 1758) 5

Arothron meleagris (Commerson \& Lacepède in Anonymus, 1798)

Arothron nigropunctatus (Bloch \& Schneider, 1801)5

Arothron stellatus (Commerson \& Lacepède

in Anonymus, 1798)

igaster bennetti (Bleeker, 1854)

Canthigaster janthinoptera (Bleeker, 1855) 2

Canthigaster solandri (Richardson, 1844) 2

Canthigaster valentini (Bleeker, 1853) 2

DIODONTIDAE

Diodon hystrix Linnaeus, 1758

Feedings habits- 1 : herbivores ; 2 : omnivores; 3 : browsers of sessile invertebrates; 4 : diurnal carnivores ; 5 : nocturnal carnivores; 6: piscivores; 7: diurnal planktivores; 8: nocturnal planktivores.

\section{Trophic structure}

Among the species sampled, $73 \%$ were carnivores, feeding on zooplankton, fish, and/or invertebrates (Fig. 2). Among those, the small diurnal (Labridae) and nocturnal (Lutjanidae, Lethrinidae) carnivores were the most highly represented species, composing 23 and $17 \%$, respectively of those species observed, followed by piscivores or highranking predators (Carangidae, Serranidae) composing $10 \%$, then by diurnal (Caesionidae) and nocturnal (Apogonidae, Pempheridae) planktivores, $15 \%$. Within the planktivores, the browsers of sessile invertebrate (Chaetodontidae) represented $8 \%$ of the species observed. For the other trophic categories, the herbivores (Acanthuridae, Scaridae) represented $15 \%$ of the total indexed species, while the omnivores (mainly Pomacentridae) represented $12 \%$. 


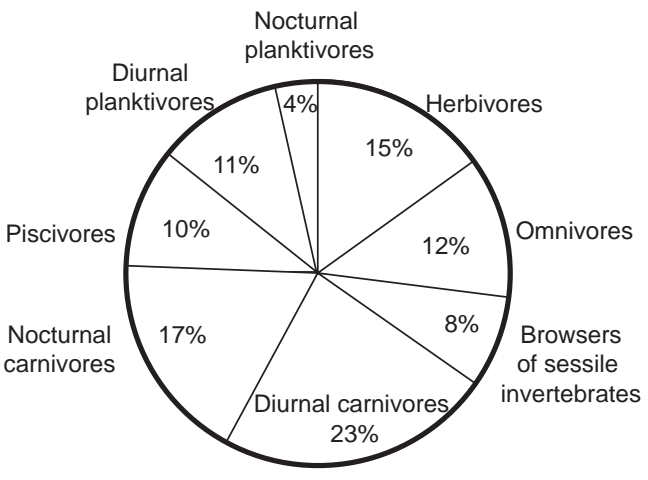

Fig. 2. Trophic structure, expressed in percentages of total number of species

\section{DISCUSSION}

\section{Species richness}

In total, 332 species were registered during this study. Despite the study's limited duration (10 days) and the use of visual observation, which typically underestimates global populations (Harmelin-Vivien et al., 1985), the fish species richness of the Glorieuses Islands proved to be elevated for isolated reefs of small surface area. Reef fish populations of small oceanic islands such as these, are sometimes considered as poor in species (Hourigan \& Reese, 1987; Randall, 1998). However, in the Cocos Islands and Malpego (eastern Pacific), a specific richness higher than 220 species was recorded (Robertson, 2001), all the while remaining inferior to that of regional fauna (on average 1/3 fewer species). In the western Indian Ocean, 294 species were recorded in Geyser and Zélée (Chabanet et al., 2002), 239 in Mayotte (Letourneur, 1996; Chabanet, 2002), 300 in Rodrigues (Heemsta et al., unpublished data), and 257 in Réunion (Chabanet, 1994); all these data were recorded using visual observation, at between 5 and $15 \mathrm{~m}$ depth. Furthermore, 305 species were indexed essentially by fishing methods in Bassas da India (Van der Elst \& Chater, 2001). Also Fricke (1999) indexed 1123 species of fish in The Mascarene Islands (Réunion, Mauritius, Rodriguez) from working on collections.

The Glorieuses Islands are unique in that though small and relatively isolated $(200 \mathrm{~km}$ of Madagascar, $250 \mathrm{~km}$ of Mayotte and $250 \mathrm{~km}$ of Aldabra), the islands possess a high species richness, even superior to that of other coral reefs in the western Indian Ocean.

Recent studies have shown that autorecruitment was frequent in isolated coral zones (Galzin et al., 1998; Jones et al., 1999; Cowen et al., 2000; Fowler et al., 2000). It could account for a significant part in the fish recruitment of the Glorieuses Islands. However, given the relatively high species richness of the islands and the similarity of species to those found on neighbouring coral reefs, auto-recruitment may well be associated with a regional recruitment from other coral reefs in the zone (Geyser and Zélée coral banks, Madagascar, Comoros archipelago, The Seychelles). In the central part of northern Mozambique regional recruitment is favoured by oceanic currents (convergence zone) that occur in the central part of the northern Mozambique Channel (Piton, 1989; Benny, 2002). Moreover, no rare or new species were noted in our study.

Some families like the Carcharhinidae or the Haemulidae were represented by a single species; it is probable that others of the same family were present on these reefs. Likewise, no species of either the families Syngathidae or Priacanthidae was observed during the sampling period, although these species are otherwise common in this zone of the Indian Ocean. Further investigations will be necessary in this case, to complete this initial fieldwork. In contrast, some families, like the Serranidae, Carangidae, or Lutjanidae were observed at all sampling stations. Despite the fact that no actual measurements of the fish were taken, these individuals tended to be adult and largesized, showing almost no sign of fisheries impact and highlighting the beneficial effects of a conservation area for these families.

\section{Trophic structure}

The presence of a large number of carnivorous species on coral reefs, habitually varying between 60 and $80 \%$ of the observed species according to the geographic area considered, constitutes one characteristic of fish populations in coral reef environments (Harmelin-Vivien, 1979). As a 
Table 2. Trophic structure of the fish communities, expressed in percentages of total number of species on different Indo-Pacific coral reefs. Data were recorded on the outer slope (depth between 0 and $15 \mathrm{~m}$ )

\begin{tabular}{lllll}
\hline & & Carnivores & Omnivores & Herbivores \\
\hline Tuléar (Madagascar) & Harmelin-Vivien, 1979 & 74 & 13.5 & 12.5 \\
Réunion & Chabanet, 1994 & 51 & 24 & 25 \\
Mayotte & Chabanet, 2002 & 69 & 12.5 & 18.5 \\
Geyser et Zélée & Chabanet et al., 2002 & 69 & 16 & 15 \\
Glorieuses & This study & 73 & 12 & 15 \\
\hline
\end{tabular}

general rule, Harmelin-Vivien (1992) notes that the destruction of coral reefs (pollution, overfishing, bleaching) often results in a reduction of the number of these carnivores to the advantage of herbivores; something that does not seem to be the case in the Glorieuses Islands where the percentage of the number of carnivores species (73\%) remains one of the highest in the western Indian Ocean (Table 2). It seems that the trophic structure of the fish population has not been affected at all (or only to a minimal extent) by even the slightest anthropomorphic or natural pressure, such as the massive coral bleaching that took place in 1998 (Quod, 1999; Wendling et al., 2000). A comparison of the percentages of the number of species by trophic category with other reefs in the zone shows that the data obtained in the Glorieuses Islands came closest to that of Tuléar coral reefs in Madagascar. This particular reef, studied actively over several years, was considered as a reference in terms of health of coral environments for a long time (Harmelin-Vivien, 1979). The reef of the Glorieuses archipelago represents, as such, a healthy environment that is relatively protected from human impact.

\section{CONCLUSION}

This first survey of the fish species richness of the Glorieuses Islands highlights an exceptional patrimonial character. The isolation and the small size of this coral system do not appear to be limiting factors in terms of biodiversity. Despite an underestimation of small cryptic species and those from coastal pools that were not taken into account in this study, 332 species were indexed in just 10 days of observation, a number that is equivalent or even superior to other coral reefs in the western Indian Ocean.
The Glorieuses Islands, shielded from anthropogenic impact not only by their status and their isolation, but also by the permanent presence of a French military detachment, offer one of the rare examples of coral sanctuaries where human intervention is controlled and restricted. They are thus privileged sectors for the scientific observation of underwater fauna and flora and should be used as reference stations for sustained study of reefs on a worldwide scale.

Acknowledgements-Our thanks go out to the crew of the 'Turquoise', to the Fishing Committee of Mayotte, to the armed forces of FAZSOI, to the Gendarmerie who contributed to the smooth progression of this work and to Debbie Combeau and Anna Ottenwelter for proofreading the manuscript. The organisation of this mission was assured by the ARVAM, with financial support from the IFRECOR program.

\section{REFERENCES}

Benny, P.N. (2002) Variability of western Indian Ocean currents. Western Indian Ocean J. Mar. Sci. 1: 81-90.

Chabanet, P. (1994) Etude des relations entre les peuplements benthiques et les peuplements ichtyologiques sur le complexe récifal de St-Gilles La Saline à l'île de La Réunion. Thèse Environ. Marin, Univ. Aix-Marseille III, 235 pp. + annexes.

Chabanet, P. (2002) Coral reef fish communities of Mayotte (Western Indian Ocean) two years after the bleaching event. Mar. Fresh. Res. 53: 107113.

Chabanet, P., Tessier, E., Durville, P., Mulochau, T. \& René, F. (2002) Peuplement ichtyologique des bancs de Geyser et Zélée (Océan Indien Occidental). Cybium, 26: 11-26.

Cowen, R.K., Lwiza, K.M., Sponaugle, S., Paris, C.B. \& Olson, D.B. (2000) Connectivity of marine 
populations: open or close? Science 287: 857-859.

Fricke, R. (1999) Fishes of the Mascarene Islands (Réunion, Mauritius, Rodriguez). Königstein Koeltz Scientific Books (Ed.), 759 pp.

Fowler, A.J. (1987) The development of sampling strategies for population studies of coastal reef fishes. A case study. Coral Reefs 6: 49-58.

Fowler, A.J., Black, K.P. \& Jenkins, G.P. (2000) Determination of spawning areas and larval advection path-ways for King George in Southeastern Australia using otolith microstructure and hydrodynamic modelling. Mar. Ecol. Prog. Ser. 199: 243-254.

Gabrié, C. (1998) L'état des récifs corallines en France Outre-Mer. ICRI. Doc. Secrétariat d'Etat à l'Outre-Mer et Ministère de l'Aménagement du Territoire et de l'Environnement. 136 pp.

Galzin, R., Planes, S., Adjeroud, M., Chauvet, C., Doherty, P.J. \& Poupin, J. (1998) Objectives and background to the 1994 Franco-Australian expedition to Taiaro Atoll (Tuamotu Archipelago, French Polynesia). Coral Reefs 17: 15-21.

Harmelin-Vivien, M.L. (1979) Ichtyofaune des récifs coralliens de Tuléar (Madagascar): Ecologie et relations trophiques. Thèse d'Etat, Univ. AixMarseille II: $165 \mathrm{pp}$.

Harmelin-Vivien, M.L. (1992) Impact des activités humaines sur les peuplements ichtyologiques des récifs coralliens de Polynésie française. Cybium 16: $279-289$.

Harmelin-Vivien, M.L., Harmelin, J., Chauvet, C., Duval, C., Galzin, R., Lejeune, P., Barnabé G., Blanc, F., Chevalier, R., Duclerc, J. \& Lasserre, G. (1985) Evaluation visuelle des peuplements et populations de poissons: méthodes et problèmes. Rev. Ecol. Terre Vie 40: 467-539.

Hiatt, W.R. \& Strasburg, D.W. (1960) Ecological relationship of the fish fauna on coral reefs of the Marshall islands. Ecol. Monogr. 30: 65-127.

Hobson, E.S. (1974) Feeding relationships of Teleostean fishes on coral reefs in Kona, Hawaii. Fish Bull. 72: 915-931.

Hourigan, T.F. \& Reese, E.S. (1987) Mid-ocean isolation and evolution of Hawaiian reef fishes. Trends Ecol. Evol. 2: 187-191.
Jones, G.P., Milicich, M.J., Emslie, M.J. \& Lunow, C. (1999) Self-recruitment in a coral reef fish population. Nature 402: 802-805.

Le Corre, M., Safford, R.J. (2001) La Réunion and Iles Eparses. In: Fishpool L. \& Evans M. (eds) Important bird areas in Africa and associated islands. Priority sites for conservation. Birdlife Conservation Series, Vol. 11. pp. 693-702.

Letourneur, Y. (1996) Réponses des peuplements et populations de poissons aux réserves marines: le cas de l'île de Mayotte, Océan Indien Occidental. Ecoscience 3: 442-450.

Myers, R.F. (1999) Micronesian reef fishes. Coral Graphics, Barrigada, Guam, 298 pp.

Piton, B. (1989) Quelques aspects nouveaux sur la circulation superficielle du canal de Mozambique (Océan Indien). Doc. Sci. ORSTOM Brest, 54, $31 \mathrm{pp}$.

Quod, J.P. (1999) Consequences of the 1998 coral bleaching event for the islands of the western Indian Ocean. In: Coral reef degradation in the Indian Ocean. CORDIO SAREC Marine Science Program, Stockholm Sweden: 53-59.

Randall, J.E. (1998) Zoogeography of shore fishes of the Indo-Pacific region. Zool. Stud. 37: 227-268.

Robertson, D.R. (2001) Population maintenance among tropical reef fishes: Inferences from smallisland endemics. Proc. Nat. Acad. Sci. USA, 98: 5667-5670.

Van Der Elst, R.P. \& Chater, S. (2001) The ichthyofauna of Bassas da India atoll in the Mozambique Channel. In: Proc. $6^{\text {th }}$ Fish IndoPacific Conf., Durban (abstract, p. 61).

Vergonzanne, G. (1977) Etude sur les mollusques et les echinodermes récifaux des îles Glorieuses. Thèse Sciences, EPHE, Paris: 100 pp.

Wendling, B., Dahalani, Y., Descamp, P., Priess, K. \& Thomassin, B. (2000) Coral communities recovery at Mayotte Island (SW Indian Ocean) following the 1998 bleaching event and/or recent Acanthaster plagues. In: 9th International Coral Reef Symposium, Bali. (abstract). 